\title{
Performance of micro CHP unit based on SI engine with quantitative-qualitative load control
}

The paper presents data resulting by the preliminary experimental tests performed on a micro CHP (combined heat and power) $7 \mathrm{kWel}$ unit. The engine load has been controlled by throttle position (quantitatively) or/and the value of air excess ratio (qualitatively) $Q Q L C$. By this way the engine efficiency can be improved in the range of partial loads by reducing the exergy losses during the inlet stroke. During the tests engine has been powered with LPG fuel. The engine performance together with environmental impact has been studied in this paper. Used method shows that despite the reduction of the load from $5.6 \mathrm{~kW}$ to $4.7 \mathrm{~kW}$ while burning the lean mixture, the efficiency of electricity generation increased slightly. The efficiency grew by approx. 1.41 percentage point comparing with the results obtained for almost constant load but obtained by burning the lean mixture $(\lambda=1.3)$, followed by increased throttling and combustion of the stoichiometric mixture.

Key words: CHP, SI engine, LPG, natural gas, emission, electrical efficiency

\section{Introduction}

In the first decade of the $21^{\text {st }}$ century, there was a marked increase in electricity consumption in Poland. In the years 2000-2010 it amounted to less than 18\%, which was an increase of over $21 \mathrm{TWh}$ compared to the value recorded in 2000. Over the next eight years, i.e. in the years 2010-2018, there was a further increase and significantly higher than in the first decade because by less than $27 \%$ in relation to 2010. Recent data indicate that in 2018 electricity consumption in Poland amounted to $171 \mathrm{GWh}$ [1-3].

The growing demand for electricity in our country will most likely grow dynamically in the coming years. The previously indicated clear upward trend observed in recent decades can be considered as a proof of that statement. In addition, an increase in electricity consumption in the near future will be caused by the growing appearance of electric and plug-in hybrid vehicles on the market $[4,5]$.

With regard to these data, it may be beneficial to use local low power cogeneration systems. Microcogeneration (mCHP - micro Combined Heat and Power) can be realized based on an internal combustion engine powered by natural gas or LPG. In view of the Directive 2004/8/EC, microgeneration concerns combined generation of electricity with a maximum electrical power of less than $50 \mathrm{kWe}$. The implementation of mCHP systems can significantly contribute to the propagation of low-emission heat and electricity generation in our country. With this, a new concept of electricity generation appears with the participation of the socalled prosumers.

\section{The research object and methods}

Low power cogeneration systems powered by combustion engines can be used in residential buildings, rural buildings, public facilities, hospitals, and in particular in buildings where there is a long-term, preferably all-year round demand for heat. The use of micro-cogeneration is justified wherever it can meet the needs of one or more consumers for whom the connection to a centralized heating grid would not be economically feasible.

When using reciprocating engines in $\mathrm{mCHP}$ systems, both diesel and spark ignition engines can be utilized.
Where, it should be noted, diesel engines can be used in a dual fuel configuration, that is with the main fuel being a gas, and the combustion being initiated by a pilot dose of liquid fuel. Currently, natural gas is the most suitable fuel for feeding CHP systems, mainly due to its wide availability. In the case of hindered availability of natural gas, mCHP systems are usually powered with LPG or liquid fuel. At the same time, the liquid fuel feed is most often used for self-ignition engines.

Due to their properties, most gaseous fuels are suitable for correctly feeding internal combustion, piston engines. This is due, among other things, to their good ability to form homogeneous mixtures, which is important from the point of view of the implementation of the correct combustion process in the spark ignition engine. In addition, gaseous fuels are usually characterized by wide flammability limits. Another advantage is the fact that usually gas fuels have a higher value of the hydrogen to carbon ratio relative to liquid fuels, which leads to a reduction in $\mathrm{CO}_{2}$ emissions. Table 1 presents selected parameters of natural gas type GZ50, propane and butane.

Table 1. Properties of natural gas and propane and butane [6]

\begin{tabular}{|c|c|c|c|c|c|}
\hline Fuel & $\begin{array}{c}\text { Composition } \\
\text { (by volume) }\end{array}$ & $\begin{array}{c}\mathrm{MN} \\
-\end{array}$ & $\begin{array}{c}\mathrm{LHV} \\
\mathrm{MJ} / \mathrm{m}^{3}\end{array}$ & $\begin{array}{r}\mathrm{e}_{\mathrm{dv}} \\
\mathrm{MJ} / \mathrm{m}^{3} \\
\end{array}$ & $\begin{array}{l}\text { FL (eq. ratio) } \\
\text { lower/ upper }\end{array}$ \\
\hline $\begin{array}{l}\text { Natural } \\
\text { Gas }\end{array}$ & $\begin{array}{l}\mathrm{CH}_{4}=98.5 \% \\
\mathrm{CO}_{2}=0.1 \% \\
\mathrm{~N}_{2}=1 \% \\
\text { other: } \mathrm{C}_{2} \mathrm{H}_{6} \\
\mathrm{C}_{3} \mathrm{H}_{8}, \mathrm{C}_{4} \mathrm{H}_{10}\end{array}$ & 90 & 35.3 & 2.91 & $0.49 / 1.66$ \\
\hline Propane & $\mathrm{C}_{3} \mathrm{H}_{8}$ & 35 & 91 & 2.19 & $0.49 / 2.5$ \\
\hline Butane & $\mathrm{C}_{4} \mathrm{H}_{10}$ & 10 & 118.6 & 2.24 & $0.57 / 3.06$ \\
\hline
\end{tabular}

As can be shown from the data in Table 1 there is a significant difference in the methane number for both fuels. One of the parameters, the value of which directly affects the energy efficiency of the engine is the compression ratio. Energy efficiency increases with an increasing compression ratio. Theoretically, fuels with a higher methane number should ensure that the engine achieves higher energy efficiency. The higher value of the methane number allows to 
burn the fuel with a higher compression ratio compared to fuels with a lower methane number. It should be noted, however, that the high methane value does not guarantee proper operation of the engine with high efficiency. Different fuels are characterized by different ranges of flammability limits, burning speed, minimum ignition energy. Taking into account the mentioned values, there may be, for example, a problem with the proper combustion of lean mixtures in an internal combustion engine. Combustion of lean mixtures in internal combustion engines brings measurable benefits in the form of reduction of nitrogen oxide $\mathrm{NO}_{\mathrm{x}}$ emissions and an increase of the energy efficiency of the engine.

\section{The research object and methods}

The paper presents the results of test of a micro CHP system composed of a spark ignition engine, an asynchronous generator and heat exchangers. The micro-CHP system is being created as a result of the implementation of a scientific and research project in cooperation with the Silesian University of Technology and Budexpert sp. z o.o. Ultimately, the proposed system is to meet the energy needs of a single-family home, maintaining high annual average of the efficiency of electricity generation. The system can be assembled in various configurations, eg instead of an asynchronous machine, a synchronous machine is to be used. In this configuration, there will be a possibility of a connection with the power grid or isolated working only for the needs of the facility in which the system was installed. In Figure 1, a prototype cogeneration system with additional components is presented.

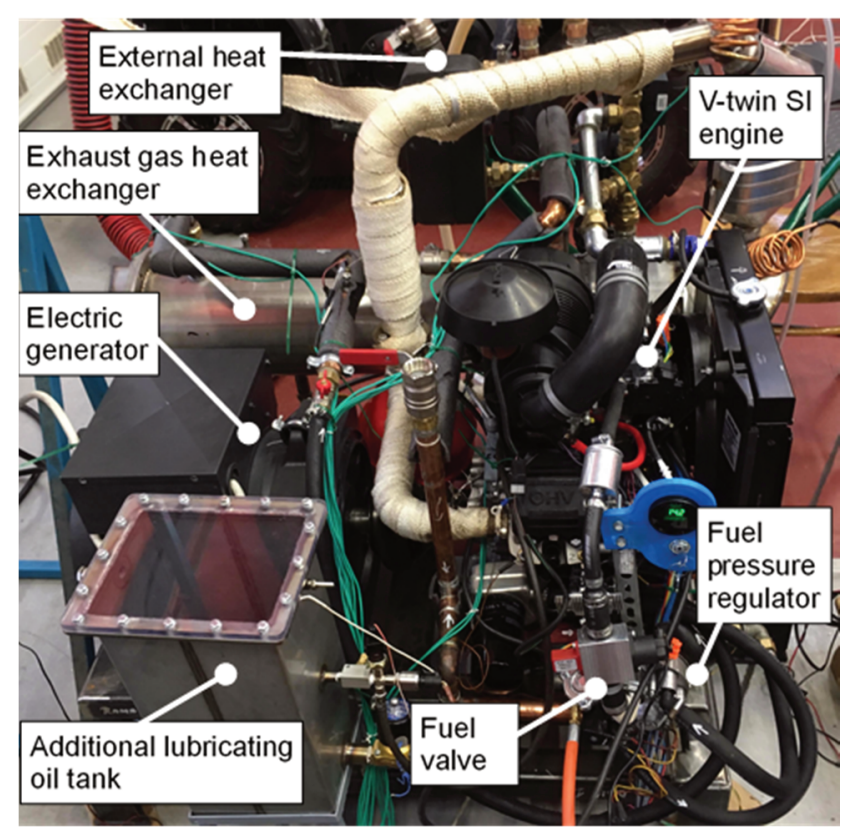

Fig. 1. The prototype cogeneration system

In residential buildings, the demand for heat is dependent on seasonal changes. For this reason, in order to fully use the potential of a co-generator it is necessary to use heat accumulators with a high heat capacity. Due to this, the internal combustion engine can start periodically and work with high efficiency, ensuring high energy efficiency of the entire cogeneration system. The installation of the heat accumulator however brings additional initial investment costs which, at the high price of low-power cogeneration systems available on the market, becomes economically unjustified.

One of the possible ways to increase the efficiency of the internal combustion engine during its operation at partial loads is to limit the loss of exergy in the inlet channel of the engine. This can be achieved by using a larger throttle opening while maintaining a certain dose of fuel to generate the required torque. This regulation leads to the formation of a lean $(1>>1)$ mixture powering the combustion engine. Depending on the properties of the fuel used, the limit value of stable operation of the internal combustion engine (flammability limit of the mixture) will vary.

The research on the prototype cogeneration unit was carried out while fuelling the engine with LPG. During the testing, the combustion engine was driving an asynchronous generator. To provide an electrical load, the system had been connected to the power grid. The heat generated by the system was transferred to a radiator with a variable cooling capacity. The electric power of the cogeneration system was modulated by changing the throttle position and thus influencing (indirectly by increasing the torque of the internal combustion engine) the change of the rotational speed of the asynchronous generator. The tests were carried out for a variable value of ignition advance angle and two different mixture compositions. Tests were carried out for three different loads of the internal combustion engine during the combustion of a stoichiometric mixture. In addition, tests were conducted for one of the three mentioned loads of the internal combustion engine while burning a lean mixture $(\lambda=1.3)$.

During the testing, the electric power was measured by the Fluke Norma 5000 power analyzer. In turn, the mass stream of fuel consumed by the engine was measured using a Sartorius weight. Also, the composition of dry exhaust gases at the outlet of the combustion engine was measured using the Capelec CAP 3000 flue gas analyzer. The temperature at selected points in the system was measured using k-type thermocouples.

\section{Research results}

On the basis of the conducted research, the energy parameters and emission factors were compared in the range of variable control parameters of the internal combustion engine. Figure 2 shows the influence of ignition advance angle on the value of electric power generated in the cogeneration system. For the stoichiometric mixture, the influence of throttling caused by the change of the throttle position is also visible. Combustion of a lean mixture with an air excess ratio $\lambda=1.3$ allows obtaining a similar value of electric power as with a stoichiometric mixture with the position of the throttle causing $15 \mathrm{kPa}$ of pressure drop. When burning a lean mixture, the pressure drop is lower and amounts to $9 \mathrm{kPa}$. At the same time achieving a comparable value of electric power requires a higher value of the ignition advance angle. The research on the combustion of lean mixtures had been limited to a single series due to high fluctuations in the electric current in the output circuit of the electrical machine. These fluctuations were caused by 
the excessive variability of the torque of the internal combustion engine due to the low value of the moment of inertia of the standard flywheel.

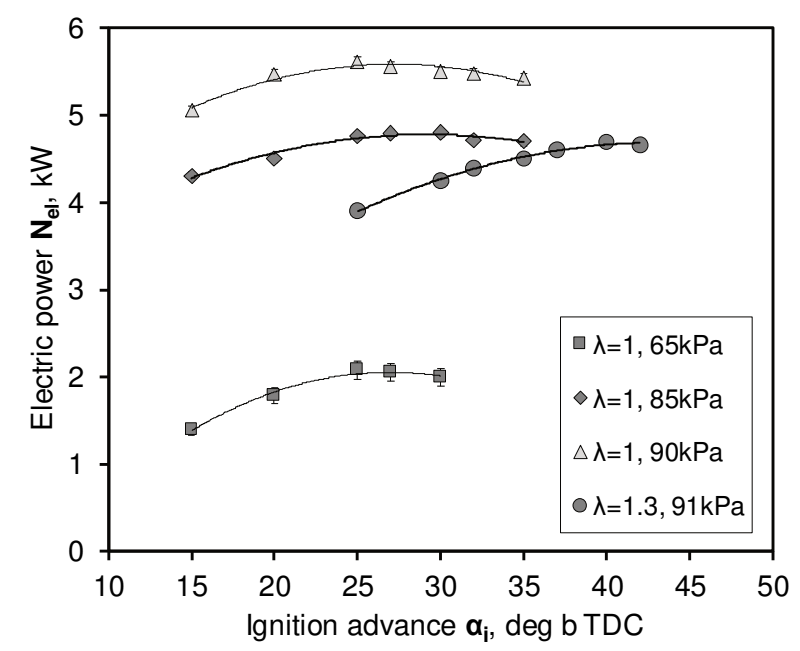

Fig. 2. Electric output power vs ignition timing, throttle position and mixture composition

Figure 3 presents the resultant values of the efficiency of electricity generation in the examined system. For the measurement series made during stoichiometric mixture combustion, the effect of the loss of exergy in the inlet channel on the level of efficiency obtained is clearly visible. For the electric power of just under $2.1 \mathrm{~kW}$, the thermal efficiency of electricity generation is $16 \%$. While for an electrical power of $5.6 \mathrm{~kW}$ efficiency reaches $25.6 \%$.

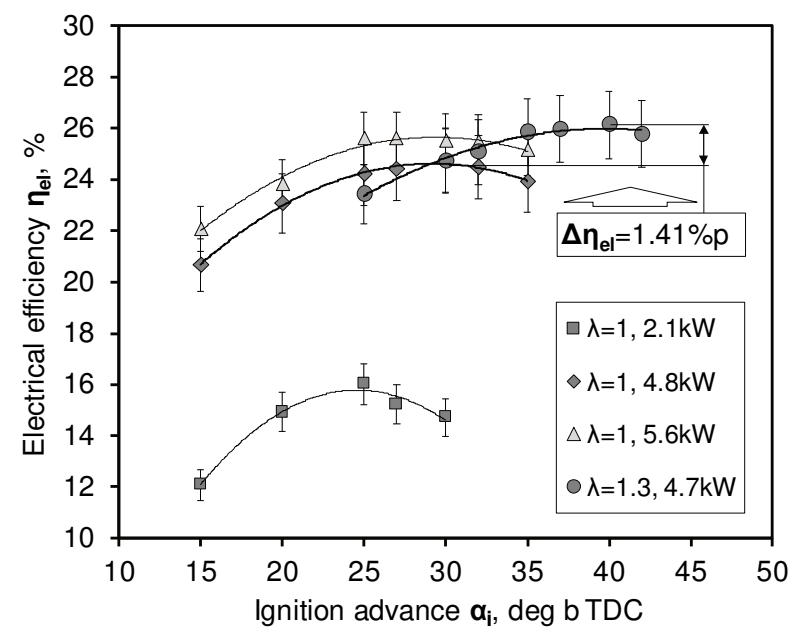

Fig. 3. Electrical efficiency vs ignition timing, throttle position and mixture composition

Figure 3 also shows the effect of using a qualityquantity regulation to limit the power output of the generator. Instead of throttling during the combustion of the stoichiometric mixture $(\lambda=1,4.8 \mathrm{~kW})$, almost the same engine output can be obtained by depleting the mixture $(\lambda=1.3$, $4.7 \mathrm{~kW}$ ) with a greater throttle opening. This treatment enables an efficiency increase of 1.41 percentage points.

Figures 4 to 10 show the specific emission and concentration of toxic exhaust substances. The concentration of individual components of the exhaust gas has been recalculated for to reference conditions corresponding to a $5 \%$ molar proportion of oxygen in dry exhaust gases. The given values have been determined for the composition of the exhaust gases measured directly at the engine outlet. The equipment used allowed to measure carbon monoxide, hydrocarbons (in terms of hexane) and nitrous oxide. $\mathrm{NO}_{\mathrm{x}}$ emission factors were calculated taking into account the $\mathrm{NO}_{2}$ molar mass.

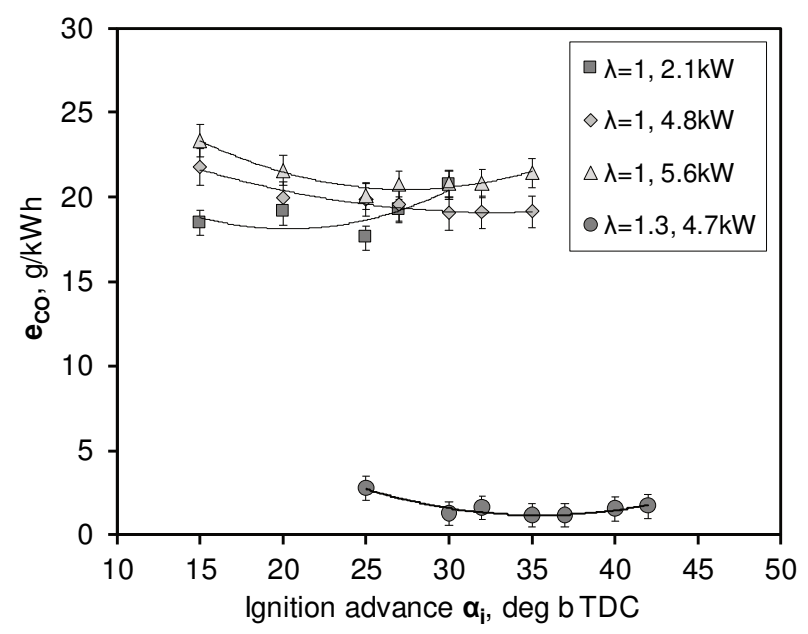

Fig. 4. Specific emission of CO vs ignition timing, throttle position and mixture composition

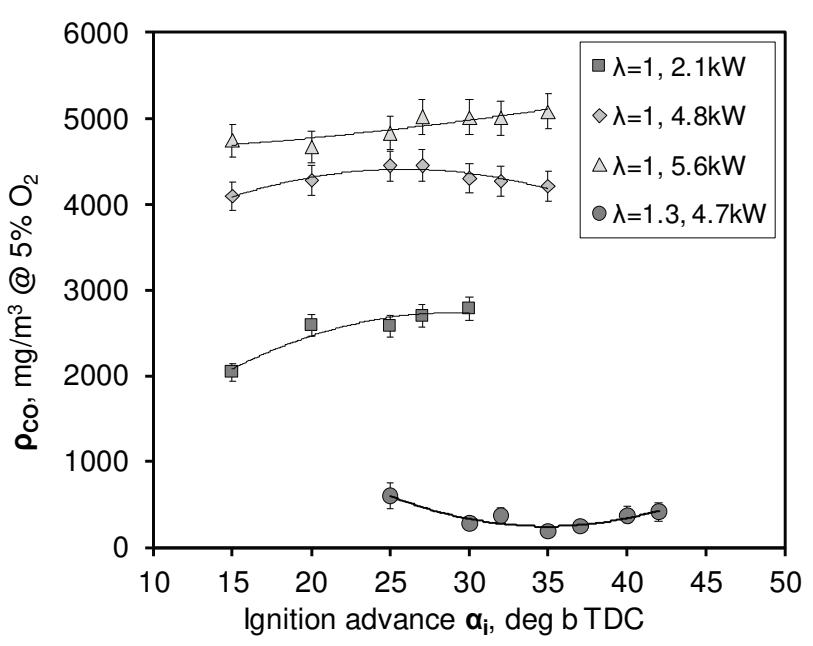

Fig. 5. $\mathrm{CO}$ concentration adjusted to $5 \%$ of $\mathrm{O}_{2}$ in dry exhaust vs ignition timing, throttle position and mixture composition

The highest level of carbon monoxide exhaust pollution is recorded for higher values of the cogeneration system load. The composition of the mixture is also significant. During the combustion of the lean mixture, the lowest values of carbon monoxide emission were obtained. The situation is similar in the case of hydrocarbon emissions. The reason may be the fact that the fuel-air mixture was prepared in a mixer whose geometry and location is still being optimized. Hence, likely the lean mix was better prepared due to the higher oxygen content in the fresh load. In addition, the lean combustion process took place at the engine load level, which ensures good thermal conditions for the combustion process. 


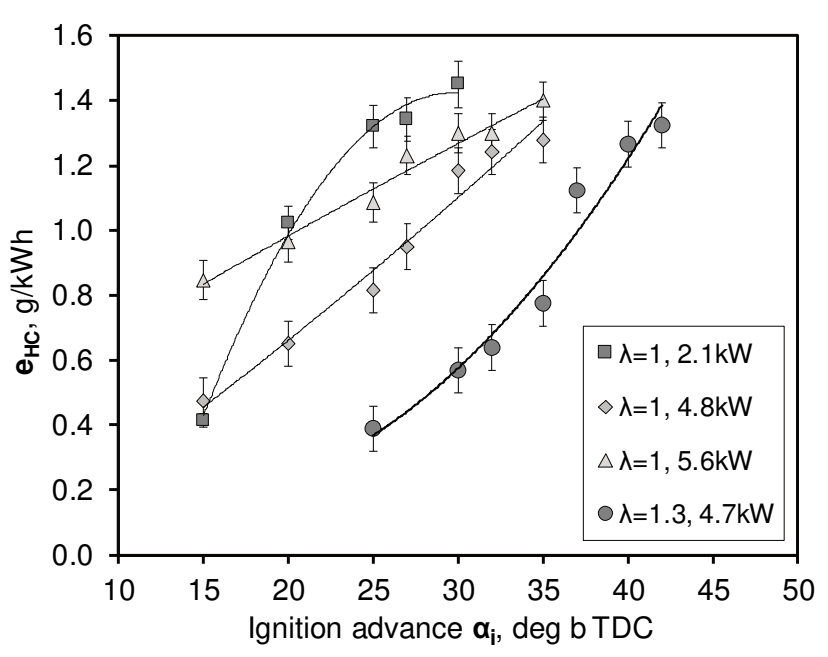

Fig. 6. Specific emission of HC vs ignition timing, throttle position and mixture composition

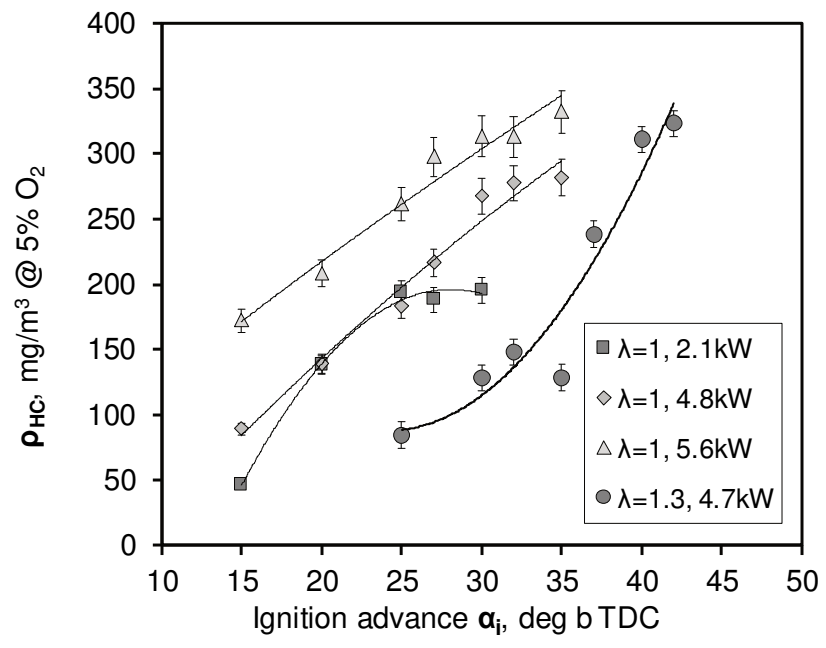

Fig. 7. HC concentration adjusted to $5 \%$ of $\mathrm{O}_{2}$ in dry exhaust vs ignition timing, throttle position and mixture composition

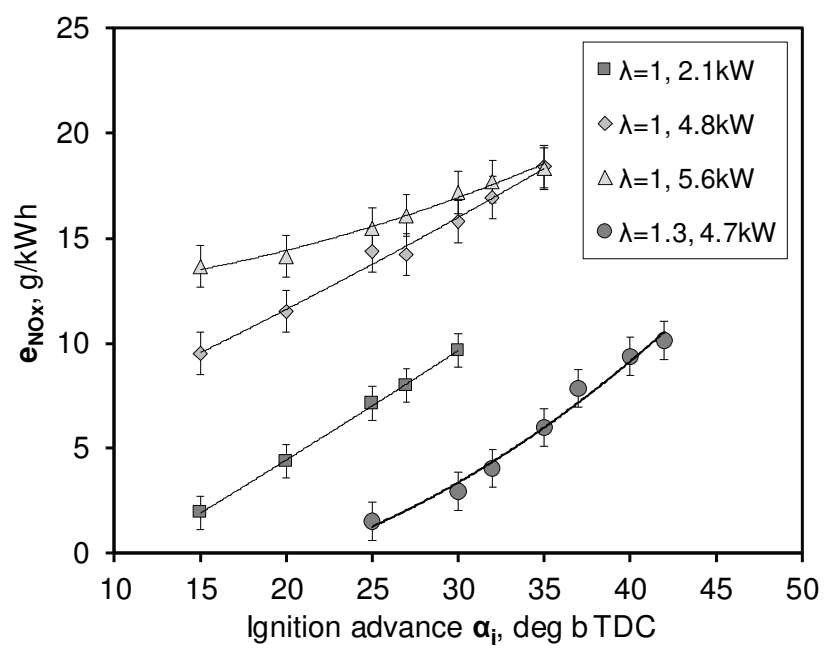

Fig. 8. Specific emission of $\mathrm{NO}_{\mathrm{x}}$ vs ignition timing, throttle position and mixture composition

The amount of nitrogen oxides emission in a spark ignition engine is closely related to the instantaneous charge temperature in the engine cylinder. The higher the value of the ignition advance angle, the higher the average temperature during the combustion process (for a specific composition of the combustible mixture). Therefore, Figures 7 and 8 show an increase in $\mathrm{NO}_{\mathrm{x}}$ emissions in proportion to the increase in ignition timing. A higher engine load (proportional to the load of the electricity generation) results in a higher value of heat generated in the cylinder. This, in turn, affects the increase of the charge temperature (for a predetermined value of the ignition advance angle). For this reason, it is evident that during the combustion of the stoichiometric mixture, the higher load of the internal combustion engine is associated with a higher emission of nitrogen oxides.

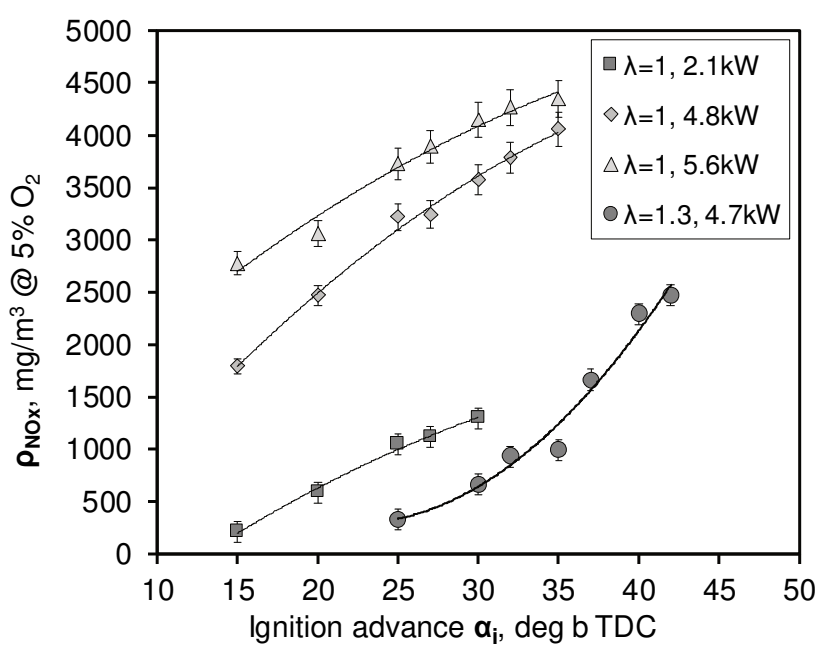

Fig. 9. $\mathrm{NO}_{\mathrm{x}}$ concentration adjusted to $5 \%$ of $\mathrm{O}_{2}$ in dry exhaust vs ignition timing, throttle position and mixture composition

Figures 10 and 11 present the results of the flue gas temperature trend measured at the outlet of the cylinder No. 1 and the cylinder No. 2 respectively. The visible temperature drop together with the increasing value of the ignition advance angle results from the course of the charge expansion. The earlier ignition leads to a higher value of the maximum pressure being reached in the engine cylinder and its location being closer to the TDC during the load expansion [7].

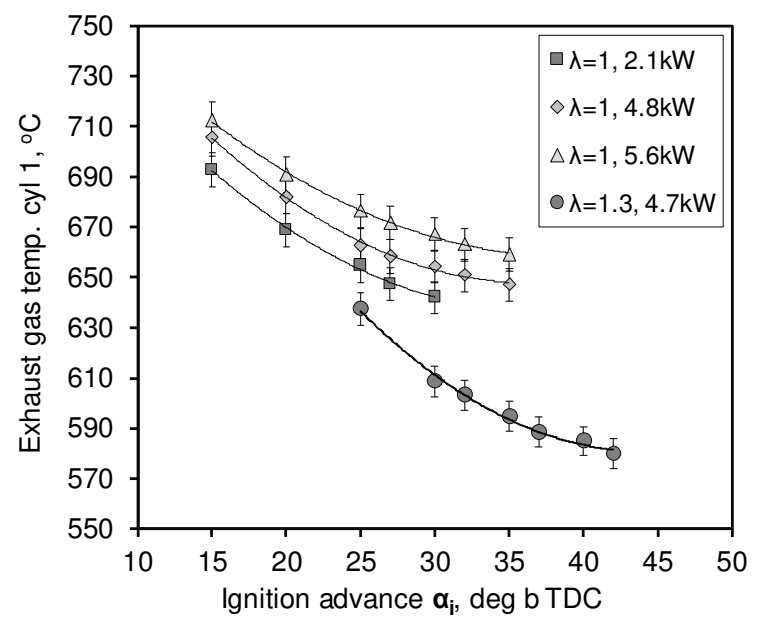

Fig. 10. Exhaust gas temperature measured on cylinder 1 outlet vs ignition timing, throttle position and mixture composition 
Variable thermal conditions during expansion significantly affect the emptying rate of the exhaust cylinder. The decreasing pressure value in the final draining phase and the amount of charge determine the temperature value in the exhaust channel. The temperature values measured in both cylinders differ slightly.

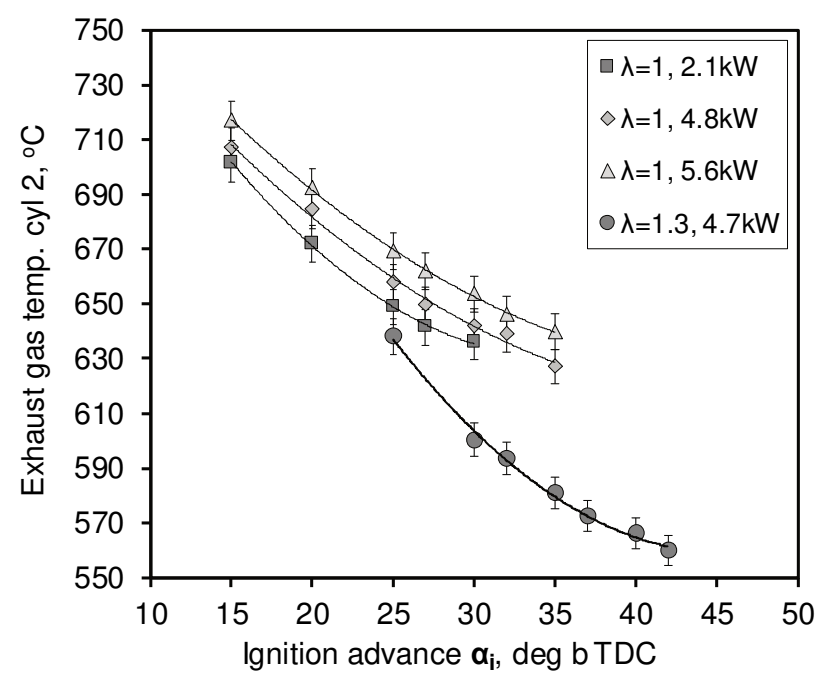

Fig. 11. Exhaust gas temperature measured on cylinder 2 outlet vs ignition timing, throttle position and mixture composition

Taking into account the quantitative and qualitative regulation, it can be noticed that the temperature of the exhaust gases is lower by approx. $50 \mathrm{~K}$ by comparing the results for the stoichiometric and lean mixture. This is in the conditions in which, the maximum power of the system during the combustion of the stoichiometric mixture was $4.8 \mathrm{~kW}$, and when burning a lean mixture it stood at $4.7 \mathrm{~kW}$.

\section{Conclusions}

The preliminary tests of the prototype microcogeneration system lead to the formulation of the following conclusions:
1. The application of the mixed regulation method, ie the combination of quantitative and qualitative regulation, gives the opportunity to increase the efficiency of electricity generation during the operation of the system with a partial load. Despite the reduction of the load from $5.6 \mathrm{~kW}$ to $4.7 \mathrm{~kW}$ while burning the lean mixture, the efficiency of electricity generation increased slightly. The efficiency grew by approx. 1.41 percentage point comparing with the results obtained for almost constant load but obtained by burning the lean mixture $(\lambda=1.3)$, followed by increased throttling and combustion of the stoichiometric mixture.

2. Combustion of lean mixtures results in greater unevenness of the engine's running, relative to the combustion of a stoichiometric mixture. Increasing the control range of the lean mixture requires the use of a flywheel with a greater moment of inertia. Its value must be selected so as to ensure stable operation of the electrical generator.

3. The use of a three-way catalytic converter will allow to reduce harmful emissions such as $\mathrm{CO}, \mathrm{HC}$ and $\mathrm{NO}_{\mathrm{x}}$. However, its correct operation will be ensured only during the combustion of stoichiometric mixtures. When combusting lean mixtures, the catalytic converter will only allow for oxidation reactions. For this reason, it is important to optimize the ignition advance angle, which on the one hand will allow to achieve a satisfactory level of energy efficiency during the combustion of lean mixtures, and on the other hand will not result in exceeding the $\mathrm{NO}_{\mathrm{x}}$ emission limit, limited by legislation.

4. Variation of the exhaust gas temperature depending on the control parameters of the internal combustion engine (ignition timing, excess air ratio) requires a proper management of the heat collection system. This will be implemented using the master cogenerator control system.

\section{Nomenclature}

$\mathrm{CO}$ carbon monoxide

$\mathrm{HC}$ hydrocarbons

$\mathrm{NO}_{\mathrm{x}}$ nitrogen oxides
MN methane number

LHV lower heating value

$\mathrm{e}_{\mathrm{dv}} \quad$ calorific value of air fuel mixture

\section{Acknowledgement}

This work was supported by the project: „Prace badawczo-rozwojowe ukierunkowane na opracowanie mikrokogeneratora o mocy elektrycznej poniżej $40 \mathrm{~kW}$ wraz z nowatorskim systemem sterowania silnikiem spalinowym i możliwościa zasilania gazem ziemnym lub $L P G$ w celu wykorzystania potencjatu innowacyjnego i stworzenia trwatej przewagi konkurencyjnej" implemented as part of the Regional Operational Program of the Silesian Region for the years 2014-2020 (European Regional Development Fund).

Fundusze Europejskie Program Regionalny
Rzeczpospolita Polska
Śląskie.
Unia Europejska
Europejski Fundusz Rozwoju Regionalnego

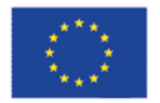




\section{Bibliography}

[1] ROLLERT, K.E. The underlying factors in the uptake of electricity demand response: The case of Poland. Utilities Policy. 2018, 54, 11-21.

[2] https://www.cire.pl/item, 149871,1,0,0,0,0,0,zuzycie-energiielektrycznej-w-polsce-rosnie.html (access 07.03.2019).

[3] GAWLIK, L., SZURLEJ, A., WYRWA, A. The impact of the long-term EU target for renewables on the structure of electricity production in Poland. Energy. 2015, 92(2), 172178.

[4] DARZI, M., JOHNSON, D., ULISHNEY, C., OLIVER, D. Gaseous fuels variation effects on first and second law analyses of a small direct injection engine for micro-CHP systems. Energy Conversion and Management. 2019, 184, 609625 .

Grzegorz Przybyła, DEng. - Institute of Thermal Technology, Silesian University of Technology. e-mail: gprzybyla@polsl.pl
[5] SPOLETINI, E. Economic analysis and technical issues of low temperature PCM thermal storage combi. Energy Procedia. Vol. 2016, 101, 1151-1158.

[6] PRZYBYLA, G., POSTRZEDNIK. S., ZMUDKA, Z. The impact of air-fuel mixture composition on SI engine performance during natural gas and producer gas combustion. Scientific conference on automotive vehicles and combustion engines (KONMOT 2016), IOP Conference Series-Materials Science and Engineering. 2016, 148. Article Number: UNSP 012082.

[7] NADALETI, W.C., PRZYBYLA, G. Emissions and performance of a spark-ignition gas engine generator operating with hydrogen-rich syngas, methane and biogas blends for application in southern Brazilian rice industries. Energy. 2018, 154, 38-51.

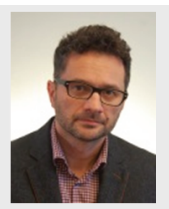

e-mail: lziolkowski@polsl.pl
Ziółkowski, MEng. - Institute of Therma
Bartłomiej Rutczyk, MEng. - Institute of Thermal Technology, Silesian University of Technology. e-mail: brutczyk@polsl.pl 